\title{
34
}

Rupantaran : A Multidisciplinary Journal

Vol. III : 34-42, March, 2020

ISSN : 2091-0061

Research Management Cell (RMC)

Dhankuta Multiple Campus, Dhankuta

Tribhuvan University, Nepal

\section{Underlying Factors for Attitude Formation: Study on Secondary School Teachers}

Hom Bahadur Basnet ${ }^{1}$

Dawa Sherpa ${ }^{2}$

\begin{abstract}
Teachers' roles are more significant in the students learning process. Thus, a teacher's attitude towards teaching and his job satisfaction have a great impact upon students' learning and their successes. Teacher's attitude towards their job affects student's achievements, student's educational outcomes. This study aims to explore the underlying factor in attitude formation of secondary school teachers in Dolakha district. For this purpose, this study has designed the research question focused on what are the determining factors for attitude formation of secondary school teachers? In this context phenomenological research design enables me to explore the participants' perceptions regarding their attitude formation towards their job. This study concluded that job security is a significant part for the attitude formation. If teachers are permanent in job nature his attitude towards his job and profession would be positive and if not, he would be negative. Only satisfied and motivated individuals perform the task well. Social values and judgement are the factors for attitude formation. The home access job and facilities of provident fund freedom of workplace create the positive attitude and absence of it make negative attitude.
\end{abstract}

Key words: Underlying Factors, Attitude Formation, School teacher

\section{Introduction}

Attitudes are evaluations of a specific person, group, their actions and objects, situations etc. It is tendency to respond in a consistently positive or negative manner with respect to a given object (Prislin and Crano, 2008). Teachers are facilitators in student's learning and creators of productive classroom environments, in which students can develop the skills they might need at present or in future. Teachers' roles

1. Mr Basnet is an Associate Professor of Foundation of Education at Tribhuvan University, Dhankuta Multiple campus, Dhankuta. Email: hombasnet14@gmail.com

2. Mr Sherpa is a Lecturer of Education Planning and Management at Tribhuvan University, Central Department of Education. 
are more significant in the student learning process. Thus, a teacher's attitude towards teaching and his job satisfaction have a great impact upon students' learning and their successes. Teachers' attitude towards their job affects students' achievements, students' educational outcomes (Hamdan, 2011).

Last year, while visiting different schools in Dolakha district in a school performance audit. Where we found newly appointed teachers are active, dedicated, responsible and motivated but most of the teachers who have been teaching for 4 to 5 years are frustrated towards their job with a negative attitude. In this context many questions arose in my mind such as what factors underlie in attitude formation? Why and how teachers' attitude towards teaching profession gradually changes with the passing of time? These queries motivated me to explore the factor underlying attitude formation among secondary school teachers in Dolakha district. In this context phenomenological research design enables me to explore the participants' perceptions regarding their attitude formation towards their job.

\section{Review of literature}

Karaaslan, (2003) state that attitudes highly influence students' interest in learning. Teachers' professional attitude in the areas of communication, classroom management and pedagogy may be a strong factor that could influence students' academic performance in schools. Attitude seen both positive and negative nature. Negative attitudes displayed in the school by teachers may result in negative performance while positive attitudes put forth by teachers in the school may result into a positive performance. Attitudes are a means for expressing personal values and other aspects of self-concept. A person who draws self-esteem from being a liberal and an environmentalist is motivated to hold attitudes that reflect these ideologies (Shaheen, 2012). The attitude of a teacher, directly or indirectly affects students' academic performance. Respecting their teaching job will go a long way in bringing about positive performance of the students while negative attitudes demonstrated by teachers in the discharge of their responsibilities may mar students' academic performance. Tabassum \& Malik (2014), argued in their study that student's attitudes were related to teacher characteristics. Teachers' characteristics influence students' performance in secondary schools.

Regarding job satisfaction, Vroom (1964) states that job satisfaction focuses on the role of the employee in the workplace. Thus, he defines job satisfaction as affective orientations on the part of individuals toward work roles which they are presently occupying. Lee and Wilbur (2010) argue that the teacher's job satisfaction and work motivation are highly influenced by their psychological states, age, sex, marital status, designation, job tenure, academic qualification, professional qualifications, training etc. Hence, a student's achievement or success is perceived as the most rewarding 
experience for every teacher. Parie and Baker (1997) found that the teachers often seem highly satisfied with their job, when the students hold outstanding results. Thus, a teacher's sense of their own success was directly correlated with the growth and well-being of his/her students. They further suggest that teachers' positive feelings concentrated by students' achievements play vital role in job satisfaction and professional attitude of teachers. Overall, teachers' job satisfaction is also determined by reorganization, responsibility, interpersonal relationships with students and colleagues, school policy, administration and teacher's own personal circumstances.

Attitude towards profession expresses feelings, behaviours and addiction of individuals towards their profession (Hussain, Ali, Khan, Ramzan \& Qadeer, 2011). Attitude of teachers towards their profession is one of the strongest indicators of their professional behaviours, this reflects their way of perceiving their profession. Current determination of these perception styles provides significant benefits upon shaping and development of the educational system. Because, it should be kept in mind that legal curriculums submitted to schools strengthen the hands of teachers. For that reason, perception styles, professional attitudes, and satisfaction levels of teachers are important in fulfilling the curriculums.

Hamdan (2011) investigate that teachers have a positive attitude towards the subject thus poor performance could be attributed to other factors than teacher attitudes. This therefore meant that the teacher's attitude directly affected students' attitude. In this study factors determining "attitude formation" have been analysed through the lens of the theory of reinforcement. The main assumption that guides this theory is that people do not like to be wrong and often feel uncomfortable when their beliefs are challenged. It states that an individual's behaviour is a function of its consequences. It is based on "law of effect", i.e., individual's behaviour with positive consequences tends to be repeated, but individual's with negative consequences tends not to be repeated.

Reinforcement theory of motivation overlooks the internal state of an individual, i.e., the inner feelings and drives of individuals are ignored by Skinner. This theory focuses what happens to an individual when he takes some action. Thus, according to Skinner, the external environment of the organization must be designed effectively and positively so as to motivate the employee. This theory is a strong tool for analysing the "controlling mechanism" of an individual's behaviour. However, it does not focus on the causes of an individual's behaviour.

In this regard the motivational factor, working environment, personnel relationship in school, students desire and interest in learning are the determinate factor for the attitude formation. On the other hand, opportunity and facilities that are important for attitude formation. 


\section{Methods and Materials}

In this study hermeneutic phenomenology research design has applied for the lived experiences of participants in natural setting (Miles, Francis, Chapman, Taylor, 2013). Community school teachers were the participants in this study. They were selected on purposive sampling. Before selecting participants, informed consent has taken and assured to withdraw if they wanted for confidentiality. Researchers details information and purpose of the study was informed for the trust worthiness. Study site was selected purposively and participants were four teachers. Two of them were teaching for two years in the same school and the other two were teaching for four years in the same school. Two teachers were permanent in job nature and two were temporary and two were local and two were from different locations. Questionnaires and in-depth interview were conducted for data collection. Data were generated through using questionnaire, in-depth interviews, interactions with participants and reflective journals. This study is delimited in context of the underlying factor of attitude formation of community school teachers which is a hilly region about four hours distance by bus from the district headquarter Dolakha. The road was just open the track and some where the road was gravelled. Hardly, Mini buses run as transportation.

For the purpose of data collection, we have developed a series of open-ended questions and in-depth interview guideline. The interviews were recorded in recorder. Descriptive account of their experiences was written which included all the events, examples, and anecdotes associated with factors associated with attitude formation. In writing those accounts, the intended outcome of this process was to create a small number of summary categories to capture the key themes in their stories. Participants were articulate enough to explain their experiences and perceptions. Recorded interviews were transcribed on paper, and coded. From the code theme were developed from the similar categories and analysed linking with theory and literature.

\section{Results and Discussion}

\section{Underlying factors for attitude formation}

Teaching is an intensely psychological process and believes a teacher's ability to maintain productive classroom environments, motivate students, and make decisions depends on her personal qualities and the ability to create personal relationships with her students (Richardson, 1996). These effective attitudes and actions employed by teachers ultimately can make a positive difference on the lives of their students. Data derived from the in-depth interviews and interactions factors underlying attitude formation are as follows; 


\section{Career opportunity}

Career opportunities can be described as successful in his or her working life so far. Donald Super's career stage model describes the career and success of the organization is measured by promotions, increases in salary, and/or status. Super's linear career stage model suggests careers take place within the context of stable, organizational structures. Individuals moved up the organization's hierarchy seeking greater extrinsic rewards (Sullivan, 1999). While conducting interview with one of the participants stated that:

Every individual is seeking for a better and comfortable life in their profession. My career isn't secure because I am not a permanent teacher, when should I leave school isn't sure. If I leave this school there are no possibilities for my next good job. This statement states that individuals are always in search of a good and comfortable lifestyle so they are seeking better career opportunities.

If there is a good career opportunity, his attitude towards his job would be positive and if not, the attitude would be negative. He feels frustrated and guilty in his job and becomes demotivated in his job. Another participant adds his argument that "there are extreme differences between permanent and temporary teachers. Permanent teachers who feel proud and no worry about their job. Permanent teachers are more satisfied with their job than temporary teachers." In support of this argument Beard and Edwards (1995) predict worse effects of job insecurity among temporary workers: temporary workers are confronted with the threat of total job loss; the probability that this threat will be realized is close to maximal; and, because temporaries may experience difficulties in finding a permanent job, the threat of job loss is perceived to be important.

In his statement justify that job security is the significant part for the attitude formation. If teachers are permanent in job nature his attitude towards his job and profession would be positive and if not, he would be negative. Only satisfied and motivated individuals perform the task well. Thus, concerned stakeholders need to be aware of the teacher's career building for the improvement of education quality.

\section{Salaries and facilities}

Salary is the basic needs of the employee. Salary is important in the most basic sense the majority of people wouldn't do their jobs if they weren't paid for it. The home access job and facilities of provident fund freedom of workplace permanent nature of job create the positive attitude and absence of it make negative attitude (Parie, \& Baker1997). Fair salary for the particular work required is also important. In this context one of my participant stated that: 
If the salary of the teacher is not going to fulfil the basic needs and demands of the teacher then the teacher is not going to be honest and sincere towards their profession instead becoming academic, they are going to engage themselves in several economic generating activities. They become less devoted towards their job. As he stated that salary is the prime factor for the employee.

If the teachers are getting sufficient salary to fulfil their basic needs, they would become dedicated responsible and honest it means their attitude towards job is positive and if not, attitude become negative. Every people join the organization for the purpose of salary that is the means for the basic needs. The salary (money) is a tool that enables people to protect themselves, to build themselves and their family a better life, and to give back to their community. Salary enables people to have more control over their life, more freedom to carve out their path and less constraints on their choices. The best education, the best health care, safety and comfort and the best start in life depends on salary. In the interview another participant explained that " $\mathrm{Job}$ security, sufficient salary, provident fund, freedom in workplace, home access job creates positive attitude towards job". His opinion highlights the value of permanent job and sufficient salaries that important for the basic needs. His views focus towards the working environment and facilities in the working situations. There shouldn't be any pressure of money to the employee to fulfil their basic needs. Employee has contributed their time and energy to the organization instead of it they aspect their security of elderly time when they unable to contribute and earn money. In this sense provident fund and pension scheme is valued by the employee. Home access job provide the employee psychological motivation and enjoy in their job because they can stay with their family, relatives and friends of their own community and feels that he/she is contributing in their community.

In conclusion, a teacher has a positive attitude if his salary has addressed his basic needs very well and he doesn't have any pressure of money. The home access job and facilities of provident fund freedom of workplace permanent nature of job create the positive attitude and absence of it make negative attitude.

\section{Social status}

Social status is the honour or prestige attached to one's position in society. Social stratification is associated with the ability of individuals to live up to some set of ideals or principles regarded as important by the society or some social group within it (Vroom, 1964) Social status describes the perception that some people occupy a "higher" or more privileged status than others deemed to rank "lower" in social standing. Social value is either inherited by birth, or implied or conferred by virtue of social, moral, economic, cultural, ethnic, or religious affluence. Teachers and 
associated groups (teaching assistants, governors and parents) consistently perceived teaching as a less rewarded, but more controlled and regulated profession than a highstatus profession. Likewise, both groups perceived a steep decline in the status of teachers over the past four decades (Hargreaves, Cunningham, Hansen, McIntyre, Oliver, and Pel, 2007). My participant in his interview stated that

Every person has a desire of social value, honour and respect in the society. In society people prefer harmonious life and try to avoid unnecessary friction of conflicts with people. Social roles and social norms can have a strong influence on attitudes. Society judgement is important in attitude formation. Social roles relate to how people are expected to behave in a particular role or context. Social norms involve society's rules for what behaviours are considered appropriate.

His statements show that how society perceived the teaching profession is the factor for the attitude formation. If society perceived positively the teacher would be motivated and make attitude positive in their profession. Social value and judgement have prioritized the money at the top rank. Another participant stated that "Though who have enough money and spend much, who have huge buildings, expensive vehicles and mobiles are valued in the society. They don't judge, how they earn? What are the sources of property?"

This statement focuses on money. How much does he/she earn in his job? Or salary factors play an important role in attitude formation because society has given high value for money. Factor for creating attitude towards job are success in work and achievement, cooperative working milieu, leave grant when required, career opportunity, democratic and appreciative leadership quality of headmaster, motivation and reward booster for teachers' job satisfaction. On the other hand, unsecured job, less salary, no fund for future, work overloads, no home access, lack of success, unfavourable environment, no leave, lack of career opportunities, autocratic nature of headmaster, lack of reward and motivation etc. were responsible for teachers' job dissatisfaction.

\section{Nature of job}

Job security is a significant part for the attitude formation. My respondent stated that "Ifteachers are permanent in job nature his attitude towards his job and profession would be positive and if not, he would be negative". Teacher makes a positive attitude if his salary has addressed his basic needs very well and he doesn't have any pressure of money. Teachers were found dissatisfied with teaching profession since they were pursuing other alternative jobs other than the teaching that could provide better payment and more prestige. The home access job and facilities of provident fund freedom of workplace permanent nature of job create the positive attitude and absence of it make negative attitude. 


\section{Conclusions}

This study conclude that only satisfied and motivated individuals perform the task well. It's very general if a teacher's salary fulfils his basic needs very well and doesn't have any pressure of money, their attitude towards job become positive. Social values and judgement are the factors for attitude formation. Society has given priority to money. Job security is a significant part for the attitude formation. If teachers are permanent in job nature his attitude towards his job and profession would be positive and if not, he would be negative. Only satisfied and motivated individuals perform the task well. Teacher makes a positive attitude if his salary has addressed his basic needs very well and he doesn't have any pressure of money. The home access job and facilities of provident fund freedom of workplace permanent nature of job create the positive attitude and absence of it make negative attitude. Social values and judgement are the factors for attitude formation. Society has given priority to money. In the context of Nepal's high salary, huge buildings, expensive vehicles and other worthy goods are the great matter in the society so teacher's salary underlies in attitude formation. The home access job and facilities of provident fund freedom of workplace permanent nature of job create the positive attitude and absence of it make negative attitude.

Study found that teacher's attitude depends on economic and social factor. Economic factors concern with basic salary and their purchasing capacity in the market as need of the society and social factor concern with people's identity, perceptions and personality towards teaching profession. Social status, value and respect in the society is the significant part in attitude formation. Thus, government's need to priorities the value of education and teaching profession. Teacher's recruitment policy, in term of qualification, nature of job, promotion policy, salaries and incentives are determinant factor for the attitude formation of teacher.

\section{References}

Adedeji, S. O. (1998). Resource provision and utilization and academic performance in pre vocational secondary school subjects in Osun State, Nigeria, (Unpublished doctoral thesis), University of Ibadan, Nigeria.

Beard, K. M., \& Edwards, J. R. (1995). Employees at risk: Contingent work and technological experience of contingent workers. Trends in Organizational Behavior,2, pp. 109-126.

Hamdan, Z. A. (2011). Teachers' attitudes towards professional development activities and their impact on their practices and motivation: a case study, Doctoral dissertation, Lebanese American University.

Hargreaves, L., Cunningham, M., Hansen, A. McIntyre, D., Oliver, C. and Pel, T. (2007) The Status of Teachers and the Teaching Profession in University of Cambridge. 
Hussain, S., Ali, R., Khan, M. S., Ramzan, M. \& Qadeer, M. Z. (2011). Attitude of secondary school teachers towards teaching profession. International Journal of AcademicResearch, 3(1), 985-990.

Karaaslan, A. D. (2003). Teachers' perceptions of self-initiated professional development: a case study on basket university English language teachers, Doctoral Dissertation, Middle East Technical University.

Kurgat, S. J and Gordon, T. J (2014). The effects of teacher characteristics and attitudes on students' achievement in Kcse Economics Examination. International Journal of Education Learning and Development 2(5), pp. 33-43.

Lee, R. \& Wilber, E.K. (2010). Job characteristics and job satisfaction, Journal of Vocational Behaviors, vol:18, pp. 362-373.

Miles, M., Francis, K., Chapman, Y., \& Taylor, B. (2013). Hermeneutic phenomenology: A methodology of choice for midwives International Journal of Nursing Practice, (19), 409-414. doi:10.1111/ijn.12082

Parie, M.\& Baker, D.P. (1997). Job satisfaction among America's teachers: effects of work place condition. ERIC Document Reproduction Service NO ED 412181.

Prislin, R., Crano, W.D.,(2008). Attitudes and attitude change: the fourth peak. In: Crano,

W.D., Prislin, R. (Eds.), Attitudes and Attitude Change. Psychology Press, New York, pp. $3-15$

Shaheen,M.(2012). Identifying the level of reflective Practices of faculty members at $\mathrm{Al}$

Quds Open University and its relationship to their attitudes towards self-professional development in the light of some variables. Journal of Al-Azhar University Gaza, Humanities, 14(2):181-208.

Tabassum, F., \& Malik, S. K. (2014). Teachers' Attitude towards Reflective Practice in Public and Private Sector at Higher Secondary Level. New educational review, 36(2), 278-288.

Vroom, V.H. (1964). Work and motivation, John Wiley and Sons, New York, p.99 